\title{
Larimar - a Unique Pectolite Rock from the Dominican Republic
}

\author{
Joanna Kowalczyk, Lucyna Natkaniec-Nowak, Jacek Wachowiak \\ AGH University of Science and Technology, Faculty of Geology, Geophysics and Environmental Protection; \\ al.Mickiewicza 30,30-059 Krakow, Poland; e-mail: joanna.j.kowalczyk@gmail.com,natkan@agh.edu.pl, psgs@agh.edu.pl
}

(C) 2015 Authors. This is an open access publication, which can be used, distributed and reproduced in any medium according to the Creative Commons CC-BY 4.0 License requiring that the original work has been properly cited.

Larimar, whose colour is varying from white lightblue, green-blue to deep blue, is only found in the Sierra de Bohoruco mountain range, Barahona Province, the Dominican Republic. It was discovered by a Spanish priest, Miguel Fuertes Lorén, in 1916 (Fuertes Marcuello \& Garcia Guinea 1990). On the basis of geological map of this region, larimar is found in a tectonic sheet of Cretaceous-Eocene rocks, mainly basalts, tuffs and tuffites which are associated to an emerged block of oceanic Caribbean crust. The basic host rock is highly serpentinized and has suffered intensive fracturing and shearing (Donnelly et al. 1990). The Dumisseau formation represented by volcanic rocks is overlain by limestones of the "Neiba formation" of the Lower Eocene-Lower Miocene age. During most of the Eocene, these carbonate rocks coexisted with, or were replaced by, volcanic materials of a tholeitic to alkaline signature (OIT to OIA), grouped under the new denomination of El Aguacate de Neiba Volcano-Sedimentary Complex, interpreted as being associated with plume. In the northern and southern areas of the Sierra de Bohoruco, coral reef limestones were deposited, representing shallow platform environments of the Oligocene-Miocene age (Huerta et al. 2007). Fault contacts are observed between the volcanic and the limestone rocks (Bente et al. 1991).

For the first time, larimar was defined as a pectolite rock by the authors of this paper. The reason for this definition is the rock's macroscopic, heterogeneous character emphasized by finely fibrous, spheroidal aggregates. The heterogeneity is also observed in the mineral composition of the rock.
Pectolite, as a major component in these rocks, is a triclinic mineral crystallized usually in veinlets, stringers, and irregular masses in volcanic rocks. Other minerals, such as calcite, natrolite, chalcedony, hematite, chalcocite, crystal formations, and occasionally hematite dendrites, coexist with pectolite and are located along the border fillings (Woodruff \& Fritsch 1989). Apatite, sphene, prehnite, danburite and datolite were also found in these heterogeneous masses (Fuertes Marcuello \& Garcia Guinea 1990). In addition, Espi \& Borrego described in 2008 an organic material associated with pectolite (indentified as volatiles), as a material which was very similar in appearance to bituminous coal.

Due to the heterogeneous character and various mineral compositions, the rock's colour changes within short distances, and shows other colours-nearly white to light greenish, greenish to greenish blue, and light bluish to blue. The origin of the larimar colour is still not obvious. It has been associated with the presence of copper coming from copper sulphide (Woodruff \& Fritsch 1989). Bente et al. (1991) suggested that vanadium was the cause of the colouration and the authors did not exclude the presence of other possible elements like $\mathrm{Fe}, \mathrm{Ti}, \mathrm{Cr}, \mathrm{Co}$, or Ni. Using a thermoluminescence dating, in light blue and blue pectolite were confirmed trace amounts of manganese (Sullasi et al. 2010). Woodruff \& Fritsch (1989) are not excluded a manganese as a colouring agent. Espi \& Borrego suggested in 2008 that organic matter might have been related to the larimar coloration. 
The petrographic studies of pectolite samples by Espi \& Borrego (2008) with SEM-EDS showed that the veins containing pectolite were associated with a variety of minerals like apatite, calcite, and impure hematite, which, except for iron and oxygen, consisted of aluminium, titanium, calcium, and gold. The chemical composition of the veins, with almost an isometric crystal and compound $\mathrm{Mg}, \mathrm{Al}, \mathrm{Si}, \mathrm{Fe}, \mathrm{K}$ and $\mathrm{Au}$, suggested the pyroxene group. SEM-EDS analyses of two samples of that rock conducted by the authors showed that impure hematite spreading in that crystalline groundmass can give alike results in polymineral composition, as colour-bearing elements, like $\mathrm{Cr}$ and $\mathrm{Cu}$. Small amounts of copper are also found together with the pectolites. Some magnesium ions occurring within pectolite aggregates suggest that this element replaced calcium ions in the pectolite structure. Its source may be found in the surrounding original wall rock, especially in pyroxene group, represented by augite. That latter group is also represented by diopside, which is typical for serpentinization as the replacement of the wall rock.

Association of pectolite with a variety of minerals, including e.g. hematite, calcite, natrolite, chalcedony, apatite, chalcocite, and crystallizations in veinlets, stringers, and irregular masses in volcanic rocks suggestes hydrothermal genesis of pectolite. The temperature in which it was formed did not exceed $250^{\circ} \mathrm{C}$ (Bente et al. 1991) and the process was strongly associated with reduced $\mathrm{CO}_{2}$ concentrations in solutions and low pressure zones (Włodyka et al. 1999).

The above conditions were found to occur in many places around the world. The question is why the bluish pectolite crystallized only in one country, the Dominican Republic.

\section{REFERENCES}

Bente K., Thum R. \& Wannemacher J., 1991. Colored pectolites, so called "Larimar", from Sierra de Bahoruco, Barahona Province, southern Dominican Republic. Neues Jahrbuch für Mineralogie - Monatshefte, 1, 14-22.

Donnelly T.W., Beets D., Carr M.J., Jackson T., Klaver G., Lewis J., Maury R., Schellenckens H., Smith A., Wadge G. \& Westercamp D., 1990. History and tectonic setting of Caribbean magmatism. [in:] Dengo G. \& Case J.E. (eds), The Caribbean Region, Geological Society of America, 13, 339-374.

Espi J.A. \& Borrego A.G., 2008. Petrographic assessment of organic material associated to pectolite deposits in Dominican Republic, implications for its genesis. International conference on Coal and organic petrology; ICCP-TSOP Joint Meeting: 60th meeting of the International Committee for Coal and Organic Petrology; 25th meeting of the Society for Organic Petrology: September 21-27, 2008, Oviedo, Spain: program and abstracts, 21-27.

Fuertes Marcuello J. \& Garcia Guinea J., 1990. Caracterización mineralógica e histórica del Larimar de Barahona (República Dominicana). Boletin del Instituto Gemológico Español, 32, 6-12.

Huerta P.P., Díaz de Neira J.A, García-Senz J., Deschamps I., Lopera E., Escuder Viruete J., Ardévol Oró Li., Granados L., Calvo J.P. \& Pérez-Estaún A., 2007. La estratigrafía de la Sierra de Neiba (República Dominicana). Boletín Geológico y Minero, 118, 2, 313-336.

Sullasi H.L., Khoury H.J., Barros V., Libonati R., Guzzo P.L., Asfora V., De Araujo R.E., Capriles M. \& Reyes J., 2010. Thermoluminescence response of the larimar rocks. $\mathrm{Ra}$ diation Measurements, 45, 540-542.

Włodyka R., Wrzalik R. \& Kapusta J., 1999. Pectolite from the Międzyrzecze dolerite sill, Bielsko-Biala vicinity. Mineralogica Polonica, 30, 3-15.

Woodruff R. \& Fritsch E., 1989. Blue pectolite from the Dominican Republic. Gems \& Gemmology, 25, 4, 216-225. 